\title{
SOSIO EMOSIONAL DALAM MODEL PEMBELAJARAN BERBASIS MASALAH TERHADAP PRESTASI BELAJAR KIMIA DITINJAU DARI KOGNITIF SISWA MADRASAH ALIYAH
}

\author{
Malikhatul Hidayah
}

\begin{abstract}
ABSTRAK
Penelitian ini bertujuan untuk menganalisis perbedaan prestasi belajar kimia dengan kondisi sosio emosional yang mencipkatan suatu kondisi yang belajar yang baik,efektif serta efisien: (1) antara siswa yang mengikuti model pembelajaran berbasis masalah dan pembelajaran eksplorasi, elaborasi, konfirmasi (EEK), (2) terhadap pengaruh interaksi model pembelajaran dengan gaya kognitif, (3) antara siswa yang mengikuti model pembelajaran berbasis masalah dan pembelajaran EEK pada siswa yang memiliki gaya kognitif field independent, dan (4) antara siswa yang mengikuti model pembelajaran berbasis masalah dan EEK pada siswa yang memiliki gaya kognitif field dependent. Penelitian ini merupakan kuasi eksperimen dengan rancangan faktorial $2 \times 2$ posttest only control group design. Subjek penelitian ini adalah siswa kelas X Madrasah Aliyah Walisongo Jepara tahun pelajaran 2013/2014. Pengambilan kelas penelitian berdasarkan teknik intake kelas. Data yang diperoleh dianalisis dengan statistik deskriptif dan Anova dua jalur. Hasil penelitian menunjukkan (1) perbedaan signifikan terhadap variable prestasi belajar kimia dan kondisi sosio emosional siswa secara bersama-sama $(\mathrm{F}=2,944 ; \mathrm{p}<0,05)$. Artinya, prestasi belajar kimia dan kondisi sosio emosional siswa bersama-sama menunjukkan perbedaan signifikan antara model pembelajaran; (2) interaksi antara model pembelajaran dan gaya kognitif secara bersama terhadap prestasi belajar kimia dan kondisi sosio emosional siswa $(\mathrm{F}=47,456$; $\mathrm{p}<0,05)$; (3) perbedaan signifikan variabel model pembelajaran terhadap prestasi belajar kimia dan kondisi sosio emosional siswa untuk siswa yang bergaya kognitif field independent ( $F=34,337 ; \mathrm{p}<0,05)$; (4) perbedaan signifikan variabel model pembelajaran terhadap prestasi belajar kimia dan kondisi sosio emosional siswa untuk siswa yang memiliki gaya kognitif field dependent $(\mathrm{F}=17,912 ; \mathrm{p}<0,05)$.
\end{abstract}

Kata Kunci: pembelajaran berbasis masalah, gaya kognitif, prestasi belajar kimia, kondisi sosio emosional siswa 


\section{PENDAHULUAN}

Penelitian ini dilatar belakangi oleh rendahnya hasil belajar yang dicapai siswa. Dari hasil pengamatan selama proses pembelajaran menunjukkan bahwa siswa kurang aktif,kurang kreatif dalam mengikuti proses pembelajaran, daya saing siswa kurang, siswa kurang percaya diri dalam memecahkan masalah, dan guru jarang melaksanakan inovasi pembelajaran. Hal ini sejalan dengan hasil observasi terhadap hasil pembelajaran kimia di kelas X MA Walisongo Jepara tahun ajaran 2013/2014, wawancara dengan guru pengajar kimia dan beberapa siswa di kelas tersebut, dapat diidentifikasi beberapa faktor penyebab rendahnya hasil belajar kimia siswa adalah sebagai berikut.

Pertama, model pembelajaran yang digunakan oleh guru dalam pembelajaran kimia sering tidak sesuai dengan perencanaan. Dalam hal ini, model pembelajaran yang dimaksud adalah model pembelajaran EEK yang mengacu pada Permendiknas RI Nomor 41 tahun 2007. Guru memang membuat rencana pelaksanaan pembelajaran sesuai dengan Permendiknas Nomor 41 tahun 2007 yang terdiri dari tahap eksplorasi, elaborasi dan konfirmasi (EEK), tetapi dalam pelaksanaannya di kelas guru sering mengabaikan tahaptahap tersebut dan lebih mengacu pada pembelajaran langsung.

Kedua, kurangnya motivasi belajar dan kondisi sosio emosional siswa dapat diamati dari partisipasi siswa di kelas yang sangat kurang. Motivasi dan kondisi sosio emosional yang lemah dalam belajar terjadi akibat dari permasalahan yang disajikan oleh guru kurang bersifat kontekstual, serta pada awal pembelajaran guru belum menggali pengetahuan awal siswa.

Ketiga, sumber belajar kimia yang ada di masyarakat dan lingkungan sekitar belum dimanfaatkan secara optimal untuk kepentingan pembelajaran. Guru kimia masih terfokus hanya pada penggunaan buku teks sebagai sumber belajar. Demikian pula LKS yang digunakan dalam proses pembelajaran belum menyentuh keterkaitan antara materi dengan konteks dalam kehidupan sehari-hari. Akibanya siswa sulit mengembangkan kemampuan berpikir dan menghubungkan antara teori dengan kondisi riil di lapangan.

Keempat, soal-soal yang diberikan pada siswa dalam ulangan 
harian maupun SAT lebih banyak menuntut siswa untuk menghafalkan atau mengulang informasi-informasi yang ada dalam buku teks, sehingga lebih menekankan aspek pengetahuan dan pemahaman, jarang sekali memberikan soal tipe aplikasi, analisis, sintesis, evaluasi maupun menciptakan. Akibatnya prestasi belajar dan kondisi sosio emosional siswa masih rendah.

Pendekatan iklim sosial - emosisonal merupakan pendekatan yang ditawarkan dalam menumbuhkan kemauan dan kemampuan bertanya siswa. Pendekata ini dilakukan dengan memberikan kesempatan kepada siswa mengajukan pertanyaan tertulis, kesempatan membacakan pertanyaan yang diajukan, kompetisi kelompok, melatih mengajukan pertanyaan tingkat rendah/ tinggi, yang didukung oleh suasana kelas yang aman, saling menghargai, dan hormat menghormati antara personal kelas. Pendekatan sosio-emosional akan tercapai secara maksimal apabila hubungan antar pribadi yang baik berkembang di dalam kelas,ubungan tersebut meliputi hubungan antara guru dan siswa serta hubungan antar siswa. Didalam hal ini guru merupakan kunci pengembangan hubungan tersebut. Oleh karena itu seharusnya guru mengembangkan iklim kelas yang baik melalui pemeliharaan hubungan antar pribadi di kelas. Untuk terciptanya hubungan guru dengan siswa yang positif, diperlukan adanya sikap saling mengerti dan sikap saling ngayomi atau sikap saling melindungi antara peserta didik dan pengajarnaya

Menurut Tiastra (2010), ada empat hal yang menyebabkan pelajaran kimia masih dianggap sulit oleh siswa, antara lain: 1) metode ceramah dan tanya jawab masih mendominasi dalam proses belajar mengajar sehingga siswa sering menganggap kimia sebagai pelajaran membosankan; 2) pelajaran kimia dianggap sulit karena banyak hitungan, banyak rumus dan bersifat abstrak serta banyak anak yang beranggapan bahwa zat-zatkimia itu beracun sehingga membahayakan mereka; 3) siswa yang belajar kimia terlepas dari tujuan kehidupan sehari-hari tetapi beroientasi untuk ulangan atau ujian; dan 4) hanya sedikit siswa yang mampu melanjutkan ke jenjang pendidikan yang lebih tinggi, ini tentunya berdampak pada rendahnya semangat siswa belajar kimia.

Sejalan dengan fakta di atas, Johari (dalam Suriti, 2011) juga 
menyatakan bahwa berbagai gejala atau fenomena yang tampak dan berkaitan dengan rendahnya prestasi belajar siswa dalam pelajaran kimia, antara lain 1) model pembelajaran yang diterapkan guru dalam pelaksanaan pembelajaran kimia kurang tepat kalau dilihat dari karakteristik pembelajaran tersebut; 2) guru cenderung kurang memberi motivasi siswa untuk belajar, sehingga minat siswa dalam belajar kimia relatif rendah; 3) siswa cenderung hanya memanfaatkan waktu yang ada di sekolah tanpa harus mengembangkan materi tambahan untuk memperluas wawasan siswa di luar jam pelajaran; 4) guru cenderung tidak mau melakukan inovasi dalam menggunakan berbagai model pembelajaran dan hanya mengandalkan metode yang sudah tidak relevan lagi dengan paradigma pembelajaran siswa saat ini; 5) dalam pembuatan silAbus dan RPP, guru sering tidak konsisten dan terkesan asal membuat; 6) siswa cenderung menganggap kimia sebagai mata pelajaran yang sulit dan mengerikan karena penggunaan model pembelajaran yang kurang tepat; dan 7) rendahnya motivasi siswa dalam belajar kimia karena menganggap pelajaran tersebut tidak dapat mendukung karir setelah memasuki dunia kerja.

Kondisi di atas berimplikasi terhadap rendahnya prestasi belajar kimia dan sosio emosional diri siswa. Pentingnya kondisi sosio emosional dikaji dalam penelitian ini tidak terlepas dari menurunnya penerapan nilai-nilai universal dalam pembelajaran di sekolah. Hal ini terlihat sering terjadi tawuran antar pelajar, siswa menggunakan obat terlarang (narkoba), tindakan menyontek saat ulangan atau ujian nasional, KKN (korupsi, kolusi dan nepotisme) yang semakin marak di negeri ini dan lain sebagainya. Ditinjau dari proses pembelajaran, ada dua asumsi yang menyebabkan gagalnya penanaman nilai-nilai universal dalam proses pembelajaran di sekolah. Pertama, munculnya anggapan bahwa persoalan penanaman nilai nilai universal adalah persoalan klasik yang penanganannya sudah menjadi bagian dari tanggung jawab guru-guru agama dan guruguru pendidikan kewarganegaran. Kedua, rendahnya pengetahuan dan kemampuan guru yang berkaitan dengan strategi penanaman dan pengintegrasian aspek-aspek nilai universal ke dalam setiap mata pelajaran yang diajarkan. 
Berdasarkan hal tersebut, setiap guru harus mampu memberikan dan menanamkan nilai-nilai universal dalam meningkatkan kondisi sosio emosional siswa sebagai generasi penerus bangsa. Hal ini bias dilakukan melalui penerapan model pembelajaran inovatif yang mampu meningkatkan motivasi dan kondisi sosio emosional siswa. Selain itu, penyebab rendahnya prestasi belajar kimia dan kondisi sosio emosional siswa juga diduga karena dalam pembelajaran guru kurang mengaitkan antara model pembelajaran inovatif dengan karakteristik yang ada pada diri siswa, yaitu gaya kognitif. Gaya kognitif merupakan bagian dari gaya belajar yang menggambarkan kebiasaan berperilaku relative tetap dalam diri seseorang dalam menerima, mengolah dan menyimpan informasi (Keefe dalam Degeng, 1989).

Berdasarkan permasalahan di atas, maka model pembelajaran berbasis masalah khususnya dalam pembelajaran kimia memegang peranan penting dalam mengembangkan dan meningkatkan prestasi belajar dan kondisi sosio emosional siswa. Selain itu, gaya kognitif juga memiliki peran penting agar tercapainya prestasi belajar dan kondisi sosio emosional siswa yang tinggi, yang semuanya itu akan terwujud melalui model pembelajaran berbasis masalah. Oleh karena itu, peneliti memandang perlu untuk melakukan penelitian tentang "Pengaruh Model Pembelajaran Berbasis Masalah terhadap Prestasi Belajar Kimia dan Kondisi sosio emosional Siswa MA Ditinjau dari Gaya Kognitif."

Penelitian ini bertujuan untuk: (1) menganalisis perbedaan prestasi belajar kimia dan kondisi sosio emosional antara kelompok siswa yang belajar dengan model PBM dibandingkan dengan kelompok siswa yang belajar dengan model pembelajaran EEK, (2) menganalisis pengaruh interaksi antara model pembelajaran dan gaya kognitif terhadap prestasi belajar kimia dan kondisi sosio emosional siswa, (3) menganalisis perbedaan prestasi belajar kimia dan kondisi sosio emosional antara kelompok siswa yang belajar dengan model PBM dan pembelajaran EEK untuk siswa yang memiliki gaya kognitif FI, dan (4) menganalisis perbedaan prestasi belajar kimia dan kondisi sosio emosional antara kelompok siswa yang belajar dengan model PBM dan pembelajaran EEK untuk siswa yang me- 
miliki gaya kognitif FD.

Penelitian ini diharapkan dapat memberikan manfaat baik secara teoritis maupun secara praktis. Secara teoritis, hasil penelitian dapat dijadikan sebagai salah satu dasar pengembangan model pembelajaran inovatif dalam dunia pendidikan khususnya kimia, serta memperkaya studi tentang model pembelajaran yang sesuai dengan memperhatikan jenis gaya kognitif siswa untuk mengatasi permasalahan terkait dengan prestasi belajar dan kondisi sosio emosional siswa. Sedangkan secara praktis, hasil penelitian ini dapat memberikan manfaat sebagai berikut. (1) Penerapan model pembelajaran berbasis masalah memberikan pengalaman langsung kepada siswa dalam menganalisis dan memecahkan masalah yang kontekstual dan merangsang mereka untuk lebih aktif dan kreatif sehingga dapat meningkatkan prestasi belajar kimia dan kondisi sosio emosional siswa; (2) Perangkat pembelajaran model PBM yang teruji ini bermanfaat kepada pengajar yang mulai menerapkan pembelajaran yang berpusat kepada siswa. Pembelajaran ini memberikan pengalaman baru, baik diri siswa maupun guru, guna lebih memudahkan menanamkan kondisi sosio emosional dan sekaligus meningkatkan prestasi belajar kimia siswa; (3) Hasil komparasi model pembelajaran ini bermanfaat bagi guru dalam mengambil peran sebagai fasilitator dan memilih model pembelajaran yang lebih baik dilakukan sesuai dengan karakteristik materi dan kemampuan siswa dalam belajar; dan (4) Penelitian ini bermanfaat bagi siswa yang mengalami kesulitan dalam memahami materi pelajaran kimia dan meningkatkan sosio emosional. Peserta didik akan menjadi lebih aktif dan termotivasi untuk belajar serta akan membimbing siswa berpikir aktif dan bertindak memecahkan masalah yang ada di lingkungan sekitar.

\section{METODE PENELITIAN}

Penelitian ini termasuk penelitian semu atau quasi eksperiment. Desain penelitian yang digunakan adalah post-test only control group design menggunakan rancangan faktorial $2 \times 2$. Populasi dalam penelitian ini adalah siswa-siswi kelas X MA Walisongo Semester Genap yang terdistribusi dalam 6 kelas (kecuali kelas rangking X1 
dan pembanding $\mathrm{X} 2$ ). Dengan teknik intake class secara bertahap, terpilih kelas X4, X7 dan X8 (untuk model PBM), kelas X3, X5 dan X6 (untuk model PEEK). Data yang diperlukan dalam penelitian ini adalah (1) skor-skor prestasi belajar kimia, (2) skor-skor kondisi sosio emosional siswa, dan (3) skor gaya kognitif siswa. Data pertama dikumpulkan dengan tes prestasi belajar kimia dan data kedua dikumpulkan dengan tes kondisi sosio emosional siswa. Tes prestasi belajar kimia berbentuk pilihan ganda terdiri dari 30 butir dan tes kondisi sosio emosional berbentuk kuisioner terdiri dari 40 butir kalimat pernyataan. Sebelum dilakukan pengujian hipotesis maka data penelitian harus memenuhi uji prasyarat yang meliputi uji normalitas sebaran data, uji homogenitas varians, uji multikolinieritas dan uji homogenitas varians-kovarians secara keseluruhan. Uji normalitas sebaran data menggunakan statistik Kolmogorov-Smirnov dan Shapiro-Wilk, sedangkan uji homogenitas varians menggunakan statistik Levene, uji multikolinieritas variabel dependen menggunakan korelasi product momen dan uji homogenitas varians-kovarians menggunakan Box's test. Selanjutnya data dianalisis secara deksriptif dan menggunakan Anova faktorial $2 \times 2$. Semua pengujian hipotesis dilakukan pada taraf signifikansi $5 \%$ dengan bantuan program SPSS 19.0 PC for Windows.

\section{HASIL DAN PEMBAHASAN \\ Hasil Penelitian}

Merujuk pada penelitian yang dilaksanakan maka distribusi data prestasi belajar kimia (PBK) dan data kondisi sosio emosional berdasarkan model pembelajaran dan gaya kognitif (GK) untuk semua sampel secara berturut-turut meliputi :

\section{Uji Prasyarat Analisis}

Uji prasyarat penting dilakukan sebelum dilakukan pengujian hipotesis. Dari hasil analisis data menunjukkan bahwa (1) untuk uji normalitas sebaran data berdistribusi normal ( $p>0,05)$; (2) untuk uji homogenitas varians menunjukkan bahwa varians antar model pembelajaran (PBM dan PEEK) dan antar gaya kognitif (FI dan FD) 
masing-masing adalah sama atau homogen, baik untuk variabel prestasi belajar kimia (PBK) maupun sosio emosional (KSE); (3) untuk uji homogenitas matriks varians-kovarians menggunakan Box's $M$ test menunjukkan bahwa nilai $F=2,552$ dengan $p>0,05$. Ini berarti bahwa matriks varians antar variabel prestasi belajar kimia maupun sosio emosional secara kolektif adalah sama (Santoso, 2002), sehingga analisis Anova dapat dilanjutkan; (4) untuk uji multikolinieritas variabel dependent menunjukkan bahwa uji korelasi antar variable dependent, yaitu prestasi belajar kimia (PBK) dan sosio emosional (KSE) didapatkan nilai korelasi antar variabel dependent sebesar 0,428. Menurut Tabachnick dan Fidel (2007), Anova akan memberikan interpretasi yang terbaik jika terdapat korelasi yang tidak begitu besar dengan koefisien korelasi bergerak $r<0,8$. Selain itu, Tabacnick dan Fidel (2007) juga mengungkapkan bahwa penggunaan Anova yang memiliki korelasi yang tinggi pada variabel dependent sangat tidak efektif. Dari hasil tersebut dapat disimpulkanbahwa uji Anova dapat dilanjutkan.

\section{Uji Hipotesis}

Untuk menganalisis hipotesis 1 dan 2 digunakan tabel hasil analisis Anova faktorial 2x 2 Terdapat perbedaan prestasi belajar kimia dan sosio emosional antara kelompok siswa yang belajar dengan model pembelajaran berbasis masalah dan model pembelajaran EEK $(\mathrm{F}=2,944 ; \mathrm{p}<0,05)$. Terdapat pengaruh interaksi antara model pembelajaran dengan gaya kognitif terhadap prestasi belajar kimia dan sosio emosional $(F=47,456 ; p<0,05)$. Merujuk hasil uji hipotesis 2 dapat diinterpretasikan bahwa variabel model pembelajaran dan gaya kognitif berinteraksi secara signifikan dalam pencapaian prestasi belajar kimia dan sosio emosional. Profil interaksi variabelvariabel independent model pembelajaran dan gaya kognitif terhadap variabel prestasi belajar kimia (PBK) dan sosio emosional (KSE) bahwa nilai rata-rata prestasi belajar kimia (PBK) kelompok MPBM lebih tinggi dibandingkan kelompok MPEEK.

Hal ini menunjukkan bahwa perbedaan kedua nilai rata-rata PBK tersebut sebagai akibat perbedaan perlakuan pada model pembelajaran. Jadi, MPBM lebih baik dalam pencapaian PBK diband- 
ingkan dengan MPEEK. Interpretasi ini mendukung hasil pengujian hipotesis H1. Apabila ditinjau dari pengaruh variabel gaya kognitif terhadap PBK, terlihat jelas bahwa nilai rata-rata PBK kelompok siswa yang memiliki gaya kognitif FI lebih tinggi dibandingkan dengan kelompok FD. Pada Gambar 02, terlihat bahwa nilai rata-rata KDS kelompok MPBM lebih tinggi dibandingkan dengan kelompok MPEEK. Hal ini berarti bahwa perbedaan kedua nilai rata-rata KDS tersebut sebagai akibat perbedaan perlakuan model pembelajaran. Jadi, MPBM lebih baik dalam pencapaian KDS dibandingkan dengan MPEEK. Untuk menganalisis hipotesis 3 digunakan tabel hasil analisis Anova factorial 2' 2 berdasarkan model pembelajaran dengan gaya kognitif FI. Berdasarkan analisis data Tabel 04 dapat diinterpretasikan bahwa terdapat perbedaan prestasi belajar kimia dan sosio emosional antara kelompok siswa yang belajar dengan model pembelajaran berbasis masalah dan model pembelajaran EEK untuk siswa yang memiliki gaya kogntif field independent $(\mathrm{F}=34,337$; $\mathrm{p}<0,05)$. Dari hasil analisis data dapat diinterpretasikan bahwa terdapat perbedaan prestasi belajar kimia dan sosio emosional antara kelompok siswa yang belajar dengan model pembelajaran berbasis masalah dan model pembelajaran EEK untuk siswa yang memiliki gaya kogntif field dependent $(\mathrm{F}=17,912 ; \mathrm{p}<0,05)$

\section{PEMBAHASAN}

Pengaruh Model PBM dan PEEK terhadap Prestasi Belajar Kimia dan Kondisi Sosio E

Berdasarkan hasil analisis data pada subbab sebelumnya menunjukkkan bahwa siswa yang belajar dengan model PBM mampu memberikan nilai prestasi belajar kimia dan sosio emosional yang lebih baik dibandingkan dengan model PEEK. Hal ini disebabkan oleh pembelajaran berbasis masalah merupakan suatu model pembelajaran yang mengkonfrontasikan siswa dengan masalahmasalah praktis, berbentuk ill-structured maupun open-ended dan menuntut keaktifan siswa dalam memecahkan masalah-masalah yang disajikan sehingga menghasilkan siswa yang mampu berpikir kritis dan menjadi problem solver mandiri.

Menurut Barrows (dalam Sadia, 2007a), terdapat enam karak- 
teristik pembelajaran berbasis masalah, antara lain: (1) proses pembelajaran bersifat student-centered, (2) proses pembelajaran berlangsung pada kelompok kecil dan setiap kelompok biasanya terdiri dari 5-8 orang, (3) guru berperan sebagai fasilitator atau pembimbing, (4) permasalahanpermasalahan yang disajikan dalam setting pembelajaran diorganisasi dalam bentuk dan fokus tertentu dan merupakan stimulus pembelajaran, (5) informasi baru diperoleh melalui belajar secara mandiri (self directed learning), dan (6) masalah merupakan wahana untuk mengembangkan keterampilan pemecahan masalah. Pembelajaran yang mengakomodasi model PBM secara teoritik mampu mengungguli model pembelajaran EEK dalam hal pembentukan konsep diri. Model pembelajaran EEK dalam diterapkan di sekolah sudah berpusat pada siswa, tetapi masih memiliki kelemahankelemahan, antara lain: (1) guru memang membuat rencana pelaksanaan pembelajaran sesuai dengan tahap EEK, tetapi dalam pelaksanaannya di kelas guru sering mengabaikan tahaptahap tersebut dan lebih mengacu pada pembelajaran langsung; (2) permasalahan yang ada pada LKS sudah disusun secara terstruktur oleh guru, sehingga siswa tinggal mengembangkan tahap-tahap atau prosedur yang diberikan. Ini akan mengurangi kontribusi siswa dalam mengeksplor kemampuan dan wawasannya dalam memecahkan masalah; dan (3) terbuka peluang guru memiliki peran vital dalam pembelajaran (teacher centered). Meninjau dari kelemahan-kelemahan tersebut, maka model ini belum mampu mengakomodasi keenam indikator konsep diri secara menyeluruh. Hal ini kurang memberikan peluang bagi siswa bekerja mandiri sehingga siswa menjadi kurang aktif dan kreatif untuk mencari jawaban sendiri masalah yang dihadapinya dan lebih sering mengandalkan teman-temannya yang mempunyai kemampuan lebih, akibatnya siswa kurang memahami konsep-konsep materi yang dipelajarinya. Interaksi Model Pembelajaran dan Gaya Kognitif terhadap Prestasi Belajar Kimia dan Sosio emosional

Berdasarkan hasil analisis data penelitian menunjukkan bahwa interaksi antara model pembelajaran berbasis masalah (PBM) dan gaya kognitif field independent (FI) lebih optimal dibandingkan dengan model pembelajaran EEK dan gaya kognitif field independent (FI). 
Sebaliknya, pada kelompok siswa yang memiliki gaya kognitif field dependent (FD) yang belajar dengan model pembelajaran berbasis masalah (PBM) memiliki skor prestasi belajar kimia dan konsep diri yang lebih rendah dibandingkan dengan kelompok siswa yang memiliki gaya kognitif field dependent (FD) yang belajar dengan model pembelajaran EEK.

Temuan dalam penelitian ini sejalan dengan kerangka berpikir dan teori yang telah dibangun sebelumnya. Siswa yang memiliki gaya kognitif FI cenderung memiliki karakteristik diantaranya: menyukai tantangan, mandiri dalam kegiatan pembelajaran, menyukai kegiatan yang bersifat analisis, merupakan individu yang aktif, tidak bergantung pada guru, memiliki motivasi intrinsik, dan tidak menerima informasi begitu saja tanpa disertai bukti-bukti nyata. Berdasarkan karakteristik tersebut, maka model pembelajaran yang sesuai dengan karakteristik siswa adalah model PBM. Dalam model PBM, siswa dituntut bertanggung jawab atas pendidikan yang mereka jalani, serta diarahkan untuk tidak terlalu tergantung pada guru. Model pembelajaran ini membentuk siswa mandiri yang dapat melanjutkan proses belajar pada kehidupan dan karir yang akan mereka jalani, dengan demikian akan terjadi peningkatan prestasi belajar kimia dan sosio emosional. Ciri-ciri individu FI seperti yang dijelaskan sebelumnya merupakan kondisi yang diperlukan dalam model pembelajaran berbasis masalah, sehingga tuntutantuntutan dalam model pembelajaran berbasis masalah lebih mampu dikerjakan oleh individu FI dibandingkan dengan individu FD.

Karakteristik siswa yang memiliki gaya kognitif field dependent antara laincenderung kurang bertanggung jawab dan kurang percaya diri dalam menyelesaikan tugastugas dibebankan kepadanya. Keadaan tersebut menyebabkan siswa sulit menentukan arah kegiatan belajar, karena itu dalam kegiatan belajarnya lebih suka mempertahankan kebiasaan yang sudah ada dan kurang tertarik kepada pembaruan. Indikasi lain yaitu siswa yang memiliki gaya kognitif FD kurang aktif dalam proses pembelajaran berbasis masalah, dan cenderung bergantung pada orang lain dalam menyelesaikan tugas. Karakteristikkarakteristik tersebut membutuhkan peran guru yang lebih banyak untuk mengarahkan materi pelajaran selama proses 
pembelajaran berlangsung. Hasil penelitian menunjukkan bahwa prestasi belajar kimia dan sosio emosional pada kelompok gaya kognitif FD lebih aik dibandingkan dengan siswa kelompok gaya kognitif FI. Hal ini mengindikasikan bahwa siswa FD lebih cocok diberikan pembelajaran EEK.Pada model pembelajaran EEK, guru memberikan bimbingan dan petunjuk yang jelasdan terperinci terkait dengan materi pembelajaran. Kondisi ini sangat diperlukan oleh ndividu yang memiliki gaya kognitif FD. Peran guru yang aktif bagi siswa FD mutlak diperlukan.

\section{Pengaruh Model Pembelajaran terhadap Prestasi Belajar Kimia dan kondisi Sosio Emosional yang Memiliki Gaya Kognitif Field Independent}

Berdasarkan temuan yang diperoleh baik melalui hasil analisis deskriptif maupun analisis Anova, maka dapat diinterpretasikan bahwa siswa yang memiliki gaya kognitif FI pada model pembelajaran berbasis masalah (PBM) mampu memberikan pengaruh yang lebih baik daripada model pembelajaran EEK dalam mencapai prestasi belajar kimia dan sosio emosional. Hal ini disebabkan oleh siswa yang memiliki gaya kognitif FI memiliki kemampuan menganalisis masalah untuk memisahkan objek dari lingkungan sekitarnya, sehingga persepsinya tidak terpengaruh bila lingkungan mengalami perubahan. Selain itu, siswa yang memilki gaya kognitif FI memiliki kemampuan mengorganisasikan objek-objek yang belum terorganisir dan informasi-informasi atau temuan baru selama penyelidikan.

Karakteristik siswa yang memiliki gaya kognitif FI berimplikasi dalam proses pembelajaran, siswa yang memiliki gaya kognitif FI cenderung untuk merumuskan sendiri tujuan pembelajaran, lebih tertarik pada penguatan internal, cenderung belajar dengan motivasi intrinsik dan cenderung untuk menggunakan struktur perantara untuk mempelajari materi. Materi pembelajaran cenderung tidak diterima seperti yang disajikan melainkan diorganisir sesuai dengan kepentingannya. Materi pembelajaran yang sudah terorganisir cenderung dianalisis untuk membuat struktur materi dengan caranya sendiri. 
Kegiatan pembelajaran dengan MPEEK didahului dengan mengajukan pertanyaanpertanyaan untuk menggali pengetahuan awal siswa dan mengaitkannya dengan konsep yang akan dipelajari. Tahap-tahap pembelajaran dalam model EEK masih bersifat umum, sehingga memerlukan waktu yang lebih banyak dalam pelaksanaannya, apalagi jika diterapkan pada kelas yang gemuk. Hal ini menyebabkan proses pembelajaran menjadi kurang efektif dan dapat memangkas kreativitas siswa dalam belajar. Berdasarkan uraian tersebut, tampak bahwa MPEEK kurang memberikan peluang untuk mengembangkan kemampuan berpikir kreatif siswa. Hasil ini sesuai dengan penelitian yang dilakukan oleh Lamba (2006), menemukan bahwa siswa yang memiliki gaya kognitif FI dalam pembelajaran diberikan model PBM, rerata hasil belajarnya lebih tinggi daripada siswa yang memiliki gaya kognitif FD. Margunayasa (2009) dalam penelitianya juga menemukan bahwa pembelajaran dengan model PBM dapat meningkatkan aktivitas belajar dan kompetensi dasar sains siswa SMP Negeri 2 Singaraja. Selain itu, Sutarno (2008) dalam penelitiannya juga menyebutkan bahwa terjadi peningkatan nilai rata-rata hasil belajar siswa dalam aspek kognitif, afektif dan psikomotor, dan juga peningkatan aktivitas siswa dalam pembelajaran dengan menggunakan modul praktikum fisika. Hasil penelitian Aryantha (2011) pada SMP Negeri 1 Singaraja juga menunjukkan bahwa terjadi peningkatan penguasaan konsep untuk siswa elompok gaya kognitif FI.

\section{Pengaruh Model Pembelajaran terhadap Prestasi Belajar Kimia dan Kondisi Sosio Emosional yang Memiliki Gaya Kognitif Field Dependent}

Berdasarkan temuan yang diperoleh baik melalui hasil analisis deskriptif maupun analisis Anova, maka dapat diinterpretasikan bahwa siswa yang memiliki gaya kognitif FD pada model pembelajaran EEK memberikan pengaruh yang lebih baik daripada siswa FD pada model pembelajaran berbasis masalah (PBM) dalam mencapai prestasi belajar kimia dan sosio emosional. Hal ini didasarkan pada karakteristik dari gaya kognitif siswa, yang mana siswa FD cenderung berpikir global, memandang objek sebagai suatu kesatuan 
dengan lingkungannya, sehingga persepsinya mudah terpengaruh oleh perubahan lingkungan. Karakteristik lain yang dimiliki siswa FD adalah cenderung menerima struktur yang sudah ada karena kurang memiliki kemampuan untuk merestrukturisasi, cenderung mengikuti tujuan yang sudah ada, cenderung bekerja dengan mengutamakan motivasi eksternal, dan lebih tertarik pada penguatan eksternal,berupa hadiah atau dorongan lain. odel pembelajaran EEK yang pada proses pembelajarannya selalu Model embelajaran EEK secara garis besar kegiatan pembelajarannya meliputi (1) kegiatan pendahuluan yang meliputi apersepsi dan motivasi, (2) kegiatan inti yang meliputi eksplorasi, elaborasi dan konfirmasi, dan (3) kegiatan penutup yang meliputi kegiatan menyimpulkan hasil pembelajaran, penilaian dan refleksi, umpan balik dan tindak lanjut. Hal ini mendorong siswa yang memiliki gaya kognitif field dependent lebih antusias mengikuti pembelajaran. Oleh karena itu, peran guru dalam model pembelajaran EEK yang lebih banyak berperan aktif dalam pembelajaran sangat membantu siswa yang memiliki gaya kognitif field dependent (FD). Hal ini sejalan dengan hasil penelitian yang dilaksanakan, yaitu siswa yang memiliki gaya kognitif FD menunjukkan hasil prestasi belajar kimia dan konsep diri lebih tinggi daripada siswa FD yang belajar dengan mengikuti model PBM. Implikasi ini akan terjadi di dalam pembelajaran sehingga guru harus berusaha lebih keras dalam meningkatkan prestasi belajar kimia dan konsep diri bagi siswa yang memiliki gaya kognitif FD.

Pada model PBM, siswa yang memiliki gaya kognitif field dependent (FD) dalam pembelajarannya cenderung tidak mampu berkembang. Hal ini tentu karena karakteristik siswa FD memiliki kecenderungan menerima konsep dan materi secara umum, agak sulit menghubungkan konsep-konsep dalam materi dengan pengalaman sendiri atau pengetahuan awal yang telah mereka miliki, suka mencari bimbingan dan petunjuk dari guru, memerlukan hadiah atau penghargaan untuk memperkuat interaksi dengan guru, suka bekerja dengan orang lain dan menghargai pendapat dan perasaan orang lain, lebih suka bekerja sama daripada bekerja sendiri, kurang mampu dalam menganalisis, kurang mampu mengorganiskan informasi secara mandiri dan lebih menyukai organisasi materi yang 
disiapkan oleh guru.

\section{SIMPULAN DAN SARAN}

\section{Simpulan}

Berdasarkan hasil penelitian dan pembahasan, maka dapat disimpulkan sebagai berikut.

1. Terdapat perbedaan prestasi belajar kimia dan sosio emosional antara kelompok siswa yang belajar dengan model pembelajaran berbasis masalah dan model pembelajaran EEK ( $\mathrm{F}=2,944$; $\mathrm{p}<0,05)$.

2. Terdapat pengaruh interaksi antara model pembelajaran dengan gaya kognitif terhadap prestasi belajar kimia dan sosio emosional $(\mathrm{F}=47,456 ; \mathrm{p}<0,05)$.

3. Terdapat perbedaan prestasi belajar kimia dan sosio emosional antara kelompok siswa yang belajar dengan model pembelajaran berbasis masalah dan model pembelajaran EEK untuk siswa yang memiliki gaya kogntif field independent $(\mathrm{F}=34,337 ; \mathrm{p}<0,05)$.

4. Terdapat perbedaan prestasi belajar kimia dan sosio emosional antara kelompok siswa yang belajar dengan model pembelajaran berbasis masalah dan model pembelajaran EEK untuk siswa yang memiliki gaya kogntif field dependent $(\mathrm{F}=17,912 ; \mathrm{p}<0,05)$.

\section{Saran}

Merujuk pada analisis hasil penelitian, maka saran yang dapat disampaikan dalam penelitian ini adalah sebagai berikut.

1. Untuk tingkat SMA pada mata pelajaran kimia sub topik kimia organik, guru sebaiknya menerapkan model pembelajaran berbasis masalah. Hal ini penting karena dalam model PBM, siswa dihadapkan pada masalah-masalah riil, selanjutnya mengidentifikasi masalah, mencari solusi pemecahan masalah. Sehingga siswa dapat menguasai konsep-konsep, keterampilan, dan konsep diri positif terhadap apa yang dipelajari, serta pada akhirnya dicapai prestasi belajar yang optimal.

2. Guru sebaiknya dalam pembelajaran harus benar-benar memperhatikan tipe gaya kognitif siswa dan jenis model pembelaja- 
ran yang akan diterapkan.

3. Disarankan dalam pembelajaran selanjutnya bila menerapkan model PBM agar mampu meningkatkan seluruh aspek sosio emosional secara serempak baik kemampuan diri, kemandirian belajar, tanggung jawab dalam belajar, hubungan sosial siswa dengan siswa, hubungan sosial siswa dengan guru dan partisipasi sosial siswa.

4. Untuk kelas yang heterogen, maka guru sebaiknya memberikan pembelajaran yang mampu mengakomodasi semua gaya kognitif siswa. Pembelajaran berbasis masalah yang mampu mengakomodasi gaya kognitif siswa dapat dilihat dari penyajian LKS dan soal-soal yang memberikan ruang bagi siswa yang memiliki gaya kogntif FI dan FD, sehingga siswa yang memiliki gaya kognitif FI dan FD dapat belajar dengan optimal sesuai dengan gaya belajaranya. 


\section{DAFTAR PUSTAKA}

Aryantha, I K. D. 2011. Pengaruh Pembelajaran Experiential dan Gaya Kognitif Terhadap Pemahaman Konsep dan Kemampuan Berpikir Kreatif Pada Pokok Bahasan Kalor dan Pemuaian. Tesis PPs Undiksha Singaraja: Tidak diterbitkan.

Degeng, I. N. S. 1989. Ilmu pengajaran Taksonomi Variabel. Jakarta: Depdikbud, Ditjen Dikti, P2LPTK.

Lamba, H. A. 2006. Pengaruh pembelajaran kooperatif model STAD dan gaya kognitif terhadap hasil belajar fisika siswa SMA. Jurnal Ilmu Pendidikan 13(2), 122-128.

Margunayasa, I G. 2009. Pengaruh model pembelajaran dan gaya kognitif terhadap pemahaman konsep dan kemampuan berpikir kritis pada siswa kelas VIII SMPN 2 Singaraja. Tesis (tidak diterbitkan). Singaraja: Program Pascasarjana UNDIKSHA Singaraja.

Sadia, I W. 2007a. Pembelajaran berbasis masalah (Problem-based learning): Suatu model pembelajaran berorientasi konstruktivisme. Makalah. Disajikan dalam pelatihan pembelajaran inovatif bagi guru MIPA di lingkungan Dinas Pendidikan Kabupaten Karangasem, 22 Oktober 2011.

Suriti, K. M. 2011. Pengaruh Model Pembelajaran Berbasis Masalah terhadap Prestasi Belajar Kimia Ditinjau dari Sikap Kritis Siswa: Eksperimen pada Siswa Kelas XI IPASMA Negeri 7 Denpasar. Tesis pada Prodi Pendidikan Sains, PPs Undiksha,Singaraja. Tidak diterbitkan. 
Sutarno, E. 2008. Penerapan Siklus Belajar Experiential untuk MeningkatkanKompetensi Dasar Fisika Siswa Kelas X di SMA Negeri 2 Singaraja. JurnalPendidikan dan Pengajaran Undiksha, No. 1 TH. XXXXI Januari 2008

Tiastra, I M. 2010. Pembelajaran Kontekstual Melalui Pembuatan Tahu sebagai UpayaMeningkatkan Kualitas Pembelajaran di kelas XII IPA SMAN 1 Kubu TahunPelajaran 2007/2008. Jurnal Pendidikan Sastracarya. Vol.1 No.2 September 2010 